\title{
Chemotaxis of Biofilm Producing Pseudomonas spp. towards Refined Petroleum Oil
}

\author{
S. Dutta ${ }^{*}$ P. Singh \\ Department of Microbiology, Kanya Gurukul Campus, Gurukul Kangri University, Haridwar- \\ 249407, India
}

Received 24 January 2016, accepted in final revised form 3 February 2016

\begin{abstract}
The bioavailability of organic contaminants to the degrading bacteria is a major limitation to efficient bioremediation of sites contaminated with hydrophobic pollutants. Studies were conducted to analyze the presence of biodegrading bacteria on the sites of refinery and garage oil spills with abundance of hydrocarbons. Contaminated soils were collected from these rich hydrocarbon sites and bacteria were isolated from samples using regular bacterial media enriched with petroleum oil. These isolates were characterized for their efficiency to utilize refining petroleum oil as their energy source and then the most common isolate was characterized. Further investigations examine the formation of biofilm by naturally existing oil-degrading bacteria on refine petroleum oil degradation. Here also studied the abilities of these Pseudomonas strains to respond chemo tactically to refine petroleum oil. Microbial chemotaxis plays important role for formation of biofilm. 16S rDNA analysis of the best degrader was found to belong to the Pseudomonas species. Interestingly, one of the best isolates was found to be close to Pseudomonas aeruginosa family.
\end{abstract}

Keywords: Bioremediation; Biofilm; Chemotaxis; Pseudomonas aeruginosa.

(C) 2016 JSR Publications. ISSN: 2070-0237 (Print); 2070-0245 (Online). All rights reserved. doi: http://dx.doi.org/10.3329/jsr.v8i2.26511 J. Sci. Res. 8 (2), 199-207 (2016)

\section{Introduction}

Petroleum is one of the most important energy resources and a raw material of the chemical industry. The world depends on oil and the use of oil as fuel has contributed to intensive economic development. Although petrochemical plants and oil refineries are beneficial to society, they produce a large amount of hazardous waste. Moreover, oil spills during exploration, transportation, and refining, have caused serious environmental problems [1]. Eight million tons of petroleum is spilled into the

\footnotetext{
Corresponding author: shreyasridutta@gmail.com
} 
environment every year worldwide. Oil contamination is a severe threat for our environment and therefore invites general concern. Consequently, the remediation of oil-polluted sites has become an important issue worldwide. Petroleum was a mixture of a very large number of different hydrocarbons; the most commonly found molecules were alkanes (paraffins), cycloalkanes (naphthenes), aromatic hydrocarbons, or more complicated chemicals like asphaltenes. Petroleum diesel, also called petro diesel or fossil diesel was the most common type of diesel fuel. It was produced from the fractional distillation of crude oil between $200^{\circ} \mathrm{C}\left(392^{\circ} \mathrm{F}\right)$ and $350^{\circ} \mathrm{C}\left(662^{\circ} \mathrm{F}\right)$ at atmospheric pressure, resulting in a mixture of carbon chains that typically contain between 8 and 21 carbon atoms per molecule. As well as kerosene was a mixture of hydrocarbons. The chemical composition depends on its source, but it usually consists of about 10 different hydrocarbons, each containing 10 to 16 carbon atoms per molecule. The main constituents were saturated straight-chain and branchedchain paraffins, as well as ring-shaped cycloparaffins (also known as naphthenes). Kerosene was less volatile than gasoline. Therefore, refined oils (i.e petrol, diesel, kerosene) have been considered as priority pollutants which exert bio-hazardous effects on both human and other living organisms in the environment. Fortunately, this mixture represents an excellent substrate in the study of hydrocarbon bioremediation due to its composition. The emphasis of research now is to exploit the hydrocarbon degradation abilities of the microbial population to raise the rate of biodegradation found naturally to significantly higher rates. The enhancement of refine petroleum oil bioremediation only depends on potential strains to run the process effectively. In biological treatment it is always necessary to perform laboratory feasibility test to determine the microbial potential to degrade the pollutant [2]. One of the major factors that impede the process bioremediation is bioavailability of hydrophobic contaminants to the hydrocarbon utilizing microorganisms. Although numerous studies focused on biofilm reactor in the field of bioremediation [3], pollution by oil and other hydrocarbons solely during the oil spillage needs further attention in the context of bioavailability of microorganisms. It has been investigated earlier that this major limitation can be improved by exploiting chemotactic bacteria [4-6]. Microbial chemotaxis plays important role in surface colonization and biofilm formation [7]. Biofilm community is diverse and relatively stable for longer period of time [8]. The phenomenon of chemotaxis by the organisms towards the pollutants and the simultaneous attachment-detachment process maintains a constant load of biomass to the affected site in the water bodies. Potential strains have the ability of chemotaxis towards petroleum hydrocarbon. It was shown that Pseudomonas has positive chemotaxis to naphthalene and growth on naphthalene or salicylate induced the chemotactic response [9]. Several authors have also studied the bacterial chemotaxis toward environmental pollutants [10]. Ortege et al. [11] studied bacterial chemotaxis towards environmental pollutants.

The objective of this study was to isolate and identify potential microorganisms from contaminated site and examined their ability to form biofilm and chemotaxis towards refine petroleum oil. 


\section{Experimental}

\subsection{Soil sample}

Soil samples were collected form Indian Oil refinery, Haldia (W.B, India). Subsurface soil samples contaminated with refined products were collected from local area, Haridwar, India. The soil samples were collected in pre-sterilized plastic bags. The samples duly labelled were stored at $4^{0} \mathrm{C}$ for further study.

\subsection{Culture enrichment isolation and characterization of strain}

Soil samples were sieved moist using a $2 \mathrm{~mm}$ mesh screen and thoroughly mixed. $10 \mathrm{~g}$ of soil was added to $95 \mathrm{~mL}$ deionized water and then vortexes. The suspension was allowed to settle down and supernatant $(5 \mathrm{~mL})$ was used as an inoculum in $100 \mathrm{~mL}$ MSM (Minimal Salt Medium) containing $2.5 \mathrm{~mL}$ of synthetic mixture of refine petroleum oil (petrol, diesel and kerosene; 1:1:1) in an Erlenmeyer flak for $48 \mathrm{hr}$ at 35 $37^{\circ} \mathrm{C}$ on a rotary shaker at $100 \mathrm{rpm}$. An enrichment of culture was carried out in three consecutive batches, each having a span of 15 days and enriched by using previous growth as inoculums for the next. MSM [12] containing following composition [in $(\mathrm{g} / \mathrm{L})]: \mathrm{KNO}_{3}(1), \mathrm{MgSO}_{4} \cdot 7 \mathrm{H}_{2} \mathrm{O}(1), \mathrm{CaCl}_{2} \cdot 6 \mathrm{H}_{2} \mathrm{O}(0.1), \mathrm{FeSO}_{4}(0.05)$, trace element sol, $250 \mathrm{~mL}$; phosphate buffer $(1 \mathrm{M}$; $\mathrm{pH} 6.8), 20 \mathrm{~mL}$; and distilled water, $980 \mathrm{~mL}$. Trace element solution comprised (g): $\mathrm{SnCl}_{2}(0.05)$; $\mathrm{KI}(0.05), \mathrm{LiCl}(0.05), \mathrm{MnSO}_{4} \cdot 4 \mathrm{H}_{2} \mathrm{O}$ (0.08), $\mathrm{HBO}_{3}(0.05), \mathrm{ZnSO}_{4} .7 \mathrm{H}_{2} \mathrm{O}(0.10), \mathrm{CoCl}_{2} \cdot 6 \mathrm{H}_{2} \mathrm{O}(0.10), \mathrm{NiSO}_{4} \cdot 6 \mathrm{H}_{2} \mathrm{O}$ (0.10), $\mathrm{BaCl}_{2}$ (0.05), ammonium molybdate (0.05) and distilled water $1000 \mathrm{~mL}$ (all salts were dissolved in defined sequence only). In final stage, $1 \mathrm{~mL}$ of this suspension was evenly spread on to a refine petroleum oil agarose plate and then incubated at $37{ }^{\circ} \mathrm{C}$ for 3 days. Selection of microorganisms was based on better ability to grow in presence of refine petroleum oils as sole source of carbon in growth media. The isolated microorganisms were tested on the basis of colonies's size, shape, margin, consistency, opacity, elevation, pigmentation, Gram reaction and cell morphology as described in Bergey's Manual of Determinative Bacteriology [13]. Biochemical properties tested include, production of catalase, indole, urease, oxidative fermentation of sugars, methyl red test, Voges Proskauer test and citrate utilization test, gelatin utilization/liquefaction test, starch utilization test etc. [13]. Motility tests were done by stabbing cells in semisolid nutrient agar (0.7\% agar) [14].

\subsection{Growth characteristics in different oil}

This experiment was performed according to the method of Salam et al. [15] with slight modification. For that purpose, all selected bacterial species were grown in MSM with excess amount $(5 \mathrm{~mL})$ of refine petroleum oil separately such as petrol, diesel and kerosene. The individual bacterial isolate from overnight culture at log phase of growth were adjusted with sterile distilled water to give a bacterial cell count of $1.0 \times 10^{2} \mathrm{CFU} / \mathrm{g}$ 
and transferred to $100 \mathrm{~mL}$ conical flasks containing $50 \mathrm{~mL}$ of sterile-define MSM with 5 $\mathrm{mL}(10 \% \mathrm{v} / \mathrm{v})$ of petrol, diesel and kerosene separately for each isolate. The flasks were then incubated in a shaker at $150 \mathrm{rpm}$ at normal temperature for 7 days. At the end of the experiment, sets of flasks were used for the enumeration of the microbial population by pour plate technique and serial dilution method on plate count agar. Optical densities of inoculated sets of flasks were also measured by spectrophotometry (Systronics-model no: 2205) at $600 \mathrm{~nm}$ against control flasks.

\subsection{Oil biofilm development}

The isolated strains were first tested for biofilm formation on $18 \mathrm{~mm}$ glass cover slips being immersed in $15 \mathrm{~mL}$ MSM with $1 \%$ synthetic mixture of refine petroleum oils in $50 \mathrm{~mL}$ sterile falcon tubes. The organism was inoculated and incubated at $30^{\circ} \mathrm{C}$ for 4 days. The cover slips were recovered from the culture tubes, washed thoroughly in $1 \%$ saline solution aseptically, air-dried and Gram-stained. Formation of biofilm was viewed under 100X oil immersion objective using compound light microscope [14].

\subsection{Scanning electron microscopy analysis}

The cell-substrate physical interaction on cover slip was examined by scanning electron microscopy. In the case of the scanning electron microscopy, bacterial aggregates on glass cover slip were fixed with $5 \%$ glutaraldehyde for $30 \mathrm{~min}$ at room temperature and stored in refrigerator for overnight. Finally, samples were transferred in Advanced Instrumentation Research Facility, Jawaharlal Nehru University, New Delhi-110067 for SEM (Zeiss EVO40) analysis [16].

\subsection{Chemo taxis movement}

Chemo taxis was tested with drop assay [17]. For this assay, $40 \mathrm{~mL}$ of cells were harvested in the logarithmic phase of growth and resuspended in $12 \mathrm{~mL}$ of chemotaxis buffer (100 mM potassium phosphate [pH 7.0], $20 \mathrm{mM}$ EDTA). A small amount of a test attractant (synthetic mixture of refine petroleum oils) was added to the center of a dish $(1 \mathrm{~mL})$. A chemotaxis response of cells to the added compound resulted in the formation of a ring of turbidity near the center of the petri dish after $24 \mathrm{~h}$.

\subsection{Molecular characterization of selected bacterial species}

Bacterial strain of PS-I was identified by $16 \mathrm{~S}$ rDNA sequence structure from Royal Life Sciences Pvt. Ltd. (affiliated to MIDI Sherlock, USA). The 500 bases sequence of $16 \mathrm{~S}$ rDNA was obtained by sequencing. The electrophoregram of partial sequence was aligned with blast search of NCBI database. 


\section{Results and Discussion}

Three bacterial strains capable of using hydrocarbon as sole source of carbon, were isolated of which two (Ps-II, Ps-III) were recorded from the soil sample of Haldia and one from oil contaminated soil (Ps-I) of a nearby garage of Haridwar. The pure refine oils utilizing bacterial strains were isolated on petroleum agarose plate. After cultural (Table 1) morphological (Table 2) and biochemical identification (Table 3), these tested isolates were identified as Pseudomonas spp.(Ps-I, Ps-II, Ps-III).

Table 1. Cultural characteristics of selected bacterial isolates.

\begin{tabular}{ccccc}
\hline Isolated Bacteria & Size & Shape & Gram's reaction & Motility \\
\hline Ps-I & Small & Rods & Gram negative & Motile \\
Ps-II & Small & Rods & Gram negative & Motile \\
Ps-III & Small & Rods & Gram negative & Motile \\
\hline
\end{tabular}

Pseudomonas is the most frequently reported and so far most studied of hydrocarbon degradation genus [18-20]. The isolated trains were examined further for substrate utilization. Over the year, substrate specificity is newly isolated organisms has been a routine diagnostic test for speciation and identification. After substrate utilization study, it was concluded that out of three Pseudomonas spp., Ps-I showed maximum growth in presence of kerosene $\left(56.27 \times 10^{7} \mathrm{CFUg}^{-}\right)$and diesel $\left(145.90 \times 10^{7} \mathrm{CFUg}^{-}\right)$ whereas Ps-II showed maximum growth on petrol $\left(4.60 \mathrm{X} 10^{7} \mathrm{CFUg}^{-}\right)$. But in case of turbidity, Ps-II showed maximum growth in presence of petrol $(0.19 \pm 0.07)$ and diesel $(0.30 \pm 0.029)$ whereas Ps-I showed maximum growth in presence of kerosene $(0.95 \pm 0.013)$. Although Ps-III was a Pseudomonas spp. but it showed very poor growth in presence of petrol, diesel and kerosene (Table 4). These results clearly indicate that different oils were degraded and utilized by all the strains in various proportions, depending on the complexity and aliphatic and aromatic nature of the sample oil dependent on bacterial species as well. The biofilm study demonstrated that the isolated bacterial strains possess the ability to form biofilm on glass surface when grown in MSM in presence of synthetic mixture of refine oils as a sole source of carbon (Fig. 1).

Table 2. Morphological characteristics of selected bacterial isolates.

\begin{tabular}{cccccccc}
\hline $\begin{array}{c}\text { Isolated } \\
\text { Bacteria }\end{array}$ & Size & Shape & Elevation & Margin & Opacity & Texture & Pigment \\
\hline Ps-I & Big & Irregular & $\begin{array}{c}\text { Slightly } \\
\text { raised }\end{array}$ & Irregular & Opaque & Smooth & Green \\
Ps-II & Big & Irregular & $\begin{array}{c}\text { Slightly } \\
\text { raised } \\
\text { Plightly } \\
\text { raised }\end{array}$ & Irregular & Opaque & Smooth & $\begin{array}{c}\text { Brownish } \\
\text { green }\end{array}$ \\
Ps-III & Big & Irregular & Opaque & Smooth & $\begin{array}{c}\text { Bluish } \\
\text { green }\end{array}$ \\
\hline
\end{tabular}


Table 3. Biochemical characterisation of bacteria.

\begin{tabular}{lccc}
\hline \multicolumn{1}{c}{ Name of Biochemical test } & \multicolumn{3}{c}{ Code number of isolates } \\
& Ps-I & Ps-II & Ps-III \\
\hline Urease production & + & + & + \\
Nitrate reduction & + & + & + \\
Oxidase & + & + & + \\
Catalase production & + & + & + \\
Gelatin utilization & + & + & + \\
Starch hydrolysis & - & - & - \\
Indole production & - & - & - \\
M.R test & + & + & + \\
V.P test & - & - & - \\
Citrate utilization & + & + & + \\
Glucose utilization & + & + & + \\
Sucrose utilization & - & - & - \\
Mannitol utilization & + & + & + \\
Lactose utilization & + & + & + \\
Maltose utilization & + & + & + \\
\hline
\end{tabular}

Interestingly, a thick biomass was observed to be aggregated near the oil water interface on the glass slide. The bioavailability of organic contaminants to the degrading bacteria is a major limitation to efficient bioremediation of sites contaminated with hydrophobic pollutants; such limitation of bioavailability can be overcome by steady state biofilm-based reactor. The isolated Pseudomonas spp. in this study showed their ability to form biofilm on glass surface in MSM in presence of refine oil. In case of PsIII showed lower attachment than other two Pseudomonas spp. (Ps I \& Ps II). In addition to this, the chemotaxis elucidated by the bacterial adhering on biofilm could also support the fact of bacterial motility towards the refine oil. A positive chemotaxis response was visualized by the accumulation of a cloud of motile cells around the drop of oil after $24 \mathrm{~h}$. Cells of Ps-I formed a turbid ring around near the drop of refine oil to the centre of petridish. Cells of Ps-II also responded to chemotaxis movement and formed a broader and diffuse ring around the drop of oil but Ps-III formed a ring far away from the drop of oil. Ps-I showed a much denser ring of turbidity around the site of drop. These results indicate that out of three species of Ps-I had a greater chemotaxis response towards refine oil within very short period of time, whereas Ps-II slowly response but Ps-III was not sufficiently sensitive towards refines oil (Fig. 2).

Table 4. Growth characteristics of different oil. (* Average of triplicates)

\begin{tabular}{ccccccc}
\hline \multirow{2}{*}{$\begin{array}{c}\text { Code no } \\
\text { of isolate }\end{array}$} & \multicolumn{2}{c}{ Petrol } & \multicolumn{2}{c}{ Diesel } & \multicolumn{2}{c}{ Kerosene } \\
& Turbidity* & C.F.U/mL* & Turbidity* & C.F.U/mL* & Turbidity* & C.F.U/mL* \\
\hline Ps-III & $0.09 \pm 0.002$ & $1.52 X 10^{7}$ & $0.10 \pm 0.012$ & $25.60 X 10^{7}$ & $0.13 \pm 0.005$ & $5.6 \times 10^{7}$ \\
Ps-II & $\mathbf{0 . 1 9} \pm \mathbf{0 . 0 7 9}$ & $\mathbf{4 . 6 0 X 1 0}^{7}$ & $\mathbf{0 3 0} \pm \mathbf{0 . 0 2 9}$ & $117.25 X 10^{7}$ & $0.07+0.014$ & $1.04 X 10^{7}$ \\
Ps-I & $0.18 \pm 0.058$ & $2.57 X 10^{7}$ & $0.28 \pm 0.012$ & $\mathbf{1 4 5 . 9 0 X 1 0}^{7}$ & $\mathbf{0 . 9 5 + 0 . 0 1 3}$ & $\mathbf{5 6 . 2 7 X 1 0}$ \\
\hline
\end{tabular}



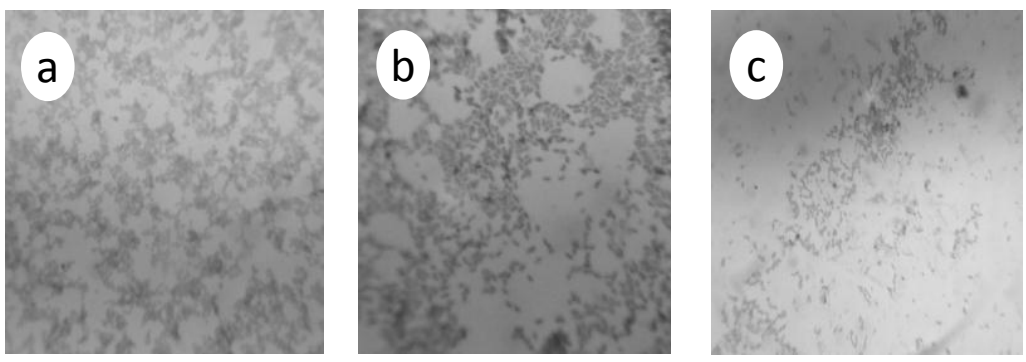

Fig. 1. Oil-biofilm formation of three bacterial isolates, [a] Ps-I, [b] Ps-II and [c] Ps-III.

Ability to form biofilm on various surfaces was always advantageous for the microorganisms in terms of survival, metabolism, adaptation, and propagation $[21,22]$. One of the major limitations faced in the process of bioremediation was the bioavailability of organic compounds on site [23]. Early studies [24] that indicate biofilm forming bacteria could be employed to overcome this limitation although the application of steady state biofilm in bioremediation was not well established. Studies indicate that biofilm-mediated bioremediation was a proficient approach and safer option since cells in biofilm had better chance of survival and adaptability especially during the stressed conditions [25,26]. Establishment of biofilm on glass slides was reported previously [26] where the artificially glued microorganisms showed excellent attenuation of crude oil in liquid waste in batch culture. Peacock et al., [22] showed altered profile of expressed proteins, specifically type VI secretion system in biofilm forming Marinobacter hydrocarbonoclasticus SP17 at alkane water interface. In this study Ps-I \& Ps-II showed good result on biofilm formation but Ps-III very limited attachments. SEM analysis permitted a 2-dimensional observation of Ps-I attached on glass cover slip. Cells were seen densely gathered on the cover slip, (Fig. 3A), linked together as clusters (Fig. 3B).

[A]

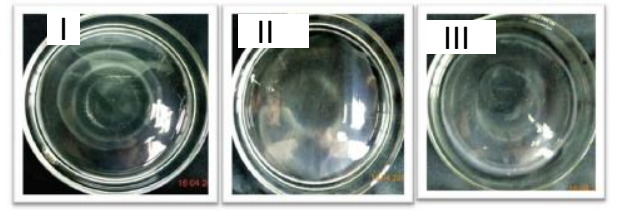

$[B]$
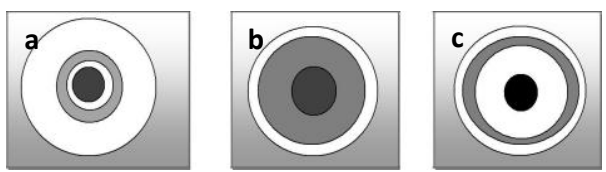

= Bacterial cell density

= attractant i.e. refine oil

Fig. 2. [A] Photograph of chemotaxis responses of Pseudomonas species ([I]: Ps-I, [II]: Ps-II, [III]: Ps-III) to refine oil. [B] Diagram of the plate [a]=[I], [b]=[II], [c]=[III]. Drawings were used because often only a small amount of contrast was visible between the accumulated cells and the background. Note that Ps-I form a broader nearer to drop of refine oil. Cells of Ps-III form a ring far away from drop of SMRP oil than cells of Ps-II. Which form a defuse ring around the drop of refine oil. 

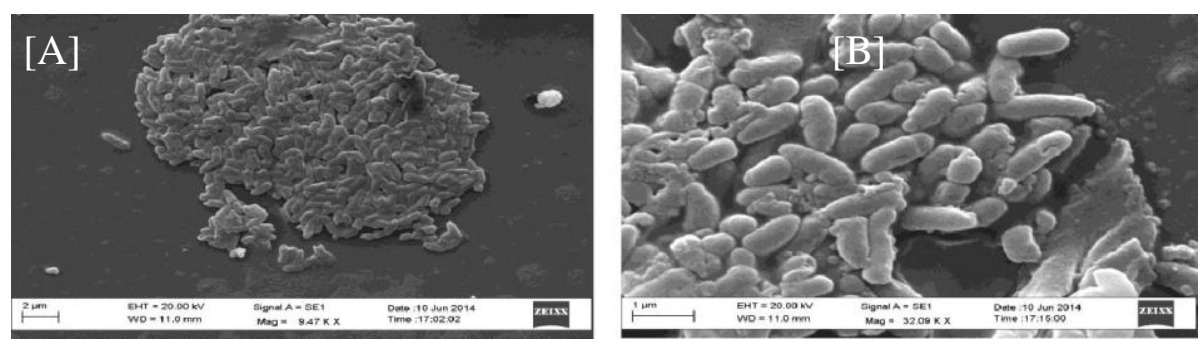

Fig. 3. (A) Cell cluster on Glass cover slip. (B) Clearly seen a road shaped Pseudomonas sp. cells present on glass cover slip.

Recent results with the biodegradation of carbon tetrachloride and naphthalene had shown the potential of chemotaxis to enhance biodegradation in laboratory-scale microcosms. Indeed, chemotaxis had already been studied in bacteria able to degrade a wide variety of organic pollutants such as naphthalene, BTEX (Benzene, Toluene, Ethylbenzene, and Xylene), and pesticides. Parales et al. [27], showed toluenedegrading bacteria were chemotaxis towards the environmental pollutants, benzene, toluene, and trichloroethylene. In addition, Harwood and Hawkins [26], showed the chemotaxis of Ralstonia to herbicide. These results indicated that out of three species of Pseudomonas sp. I had a greater chemotaxis response towards refines oil with in very short period of time whereas Pseudomonas sp.II slowly response but Pseudomonas sp.III was not sufficiently sensitive. Bacterial chemotaxis toward environmental pollutants have important role in bioremediation. Sequence aligned with NCBI database gave 98\% similarity with Pseudomonas aeruginosa. Therefore, bacterial strain of Ps-I was identified as Pseudomonas aeruginosa.

\section{Conclusion}

Pseudomonas aeruginosa strain, isolated from petroleum oil contaminated sites, showed that their ability to form biofilm and chemotaxis response towards refine petroleum oil. Therefore, these isolated Pseudomonas aeruginosa strain could be considered for future use for bioremediation of contaminated spilled oil. However, further studies are needed to evaluate the potential of the isolated strains to degrade hydrocarbons in situ, in natural environmental condition.

\section{Acknowledgment}

Authors thank to the Advanced Research Instrumental Facility, J.N.U, New Delhi for performing SEM \& Royal Life Sciences Pvt. Ltd (affiliated to MIDI Sherlock, USA) for performing bacterial molecular characterization. 


\section{References}

1. N. Das, V. Lakshmi, G. Basak, and J. A. Salam, J. Microbiol. Biotechnol. 2(5), 783 (2012).

2. $\quad$ S. Dutta and P. Singh, Int. J. Adv. Res. 2(1), 898 (2014).

3. S. Dutta and P. Singh, Int. J. Basic Appl. Bio. 1(1), 6 (2014).

4. R. Singh, D. Paul, and R. K. Jain, Trends in Microbiol. 14(9), 389 (2006). http://dx.doi.org/10.1016/j.tim.2006.07.001

5. D. Paul, G. Pandey, J. Pandey, and R. K. Jain, Trends Biotechnol. 23(3), 135 (2005). http://dx.doi.org/10.1016/j.tibtech.2005.01.001

6. G. Pandey and R. K. Jain, Appl. Environ. Microbiol. 68(12), 5789 (2002). http://dx.doi.org/10.1128/AEM.68.12.5789-5795.2002

7. R. Morgan, S. Kohn, S. H. Hwang, D. J. Hassett, and K. Sauer, J. Bacteriol. 188(21), 7335 (2006). http://dx.doi.org/10.1128/JB.00599-06

8. P. Chandran and N. Das, Biodegradation 22(6), 1181 (2011). http://dx.doi.org/10.1007/s10532-011-9473-1

9. G. Bødtker, T. Thorstenson, and B. L. P. Lillebø, J. Ind. Microbiol. Biotechnol. 35(12), 1625 (2008). http://dx.doi.org/10.1007/s10295-008-0406-x

10. G. Pandey and K. J. Rakesh, Environ. Microbiol. 68, 5789 (2002). http://dx.doi.org/10.1128/AEM.68.12.5789-5795.2002

11. J. J. Ortege-calvo, A. J. Marchenko, A. V. Vorobyov , and R. V. Borovick, FEMS. Microbiol. Ecol. 44, 373 (2003). http://dx.doi.org/10.1016/S0168-6496(03)00092-8

12. R. Whittenburry, K. C. Phillip, and J. E. Wilkinson, J. Gen. Microbiol. 61, 205 (1970). http://dx.doi.org/10.1099/00221287-61-2-219

13. J. G. Holt, N. R. Krieg, P. H. A. Sneath, J. T. Stally, and S. T. Williams, Bergey's Manual of Determinative Bacteriology [M], $9^{\text {th }}$ edition (Baltimore, Williams and Wikins., 1994) pp. 73, 129, 190, 191-253.

14. D. Dasgupta, R. Ghosh, and T. K. Sengupta, ISRN Biotechnol. Article ID 250749 (2013). http://dx.doi.org/10.5402/2013/250749

15. L. B. Salem, O. S. Obayori, and G. O. Okogie, Int. J. Agric. Biol. 13, 245 (2011).

16. C. A. Rocha, A. M. Pedregosa, and F. Laborda, AMB Express 1, 9 (2011). http://dx.doi.org/10.1186/2191-0855-1-9

17. A. C. Grimm, C. S. Harwood, Appl. Environ. Microbiol. 63, 4111 (1997).

18. S. Muthuswamy, A. R. Binupriy, S. H. Baik, S. E. Yu, Clean 36 (1), 92 (2008).

19. K. S. Gomare, M. N. Lahane, Int. J. Recent Trends Sci. Technol. 1(1), 09 (2011).

20. A. Mittal and P. Singh, J. Sci. Res. 2(1), 127 (2010). http://dx.doi.org/10.3329/jsr.v2i1.2601

21. A. D. Peacock, Y. J. Chang, and J. D. Istok, Microbial Ecol. 47(3), 284 (2004). http://dx.doi.org/10.1007/s00248-003-1024-9

22. A. D. Peacock, L. Prat, S. Mangenot, S. Cruveiller, P. Goulas, and R. Grimaud, Res. Microbiol. 160(10), 829 (2009). http://dx.doi.org/10.1016/j.resmic.2009.09.010

23. R. Singh, D. Paul, and R. K. Jain, Trends in Microbiol. 14(9), 389 (2006). http://dx.doi.org/10.1016/j.tim.2006.07.001

24. J. Wimpenny, W. Manz, and U. Szewzyk, FEMS Microbiol. Rev. 24(5), 661 (2000). http://dx.doi.org/10.1111/j.1574-6976.2000.tb00565.x

25. H. Al-Awadhi, R. H. Al-Hasan, N. A. Sorkhoh, S. Salamah, and S. S. Radwan, Int. Biodeter. Biodegr. 51(3), 181 (2003). http://dx.doi.org/10.1016/S0964-8305(02)00140-3

26. C. S. Harwood, A. C. Hawkins, Appl. Environ. Microbiol. 68, 968 (2002). http://dx.doi.org/10.1128/AEM.68.2.968-972.2002 